Menu

Search in: Anywhere

\begin{tabular}{|l|}
\hline Journal \\
\hline Enter words / phrases / D
\end{tabular}

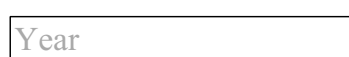

Volume

Issue

Page

Search Advanced

Customer Services

$\underline{\log \text { In } \mid \underline{\text { Register }}}$

|

google test

$\square$

- $\underline{\text { Journals }}$

- Browse

- Librarians

- Journal Ordering and Pricing

- Subscription Activation

- Open Access

- Edinburgh Journals Archive

- Journal Collections

- Usage Statistics

- Customer Services

- Authors

- Article Submissions

- Proposal Guidelines

- How to Subscribe

- Open Access

- Permissions

- Customer Services

- Societies

- Publishing Partnerships

- Benefits

- Proposal Guidelines

- Customer Services

- Open Access

- Open Access Journals

- Edinburgh Open

- Archiving and Social Sharing

- Browse Open Access Articles

- Browse Open Access Books

- About Us

- Company Information

- $\underline{\text { Contact Us }}$

- Annual Report

- Publication Ethics

- Company Home

- $\underline{B l o g}$

- $\underline{\text { Books }}$

Enter words / phrases / D

Search

Advanced Search

You are here:

- Home /

- Film-Philosophy /

- List of Issues

- Volume 8, Issue $2 /$

- Spinoza and the Politics of The Matrix, on Matrix, machine philosophique

Share 
Spinoza and the Politics of The Matrix, on Matrix, machine philosophique

....Show full title

Recommend to Library

Article Tools $\quad$.

Duncan Chesney

Duncan Chesney

$\underline{\text { Search for articles by this author }}$

Bilkent University, Ankara, Turkey

+ Show all authors

Additional Info

Citation Information: Film-Philosophy, Volume 8 Issue 2, ISSN \$ \{article.serial.IDs.ISSN.value\} Available Online Apr 2018

(https://doi.org/10.3366/film.2004.0015)

This article is published as Open Access under the terms of the Creative Commons Attribution Licence (CC-BY)

(http://creativecommons.org/licences/by) which permits re-use, distribution and reproduction provided the original work is cited.

- Citation

- Full Text

-

Alain Badiou, Thomas Benatouil, Elie During, Patrice Maniglier, David Rabouin, and Jean-Pierre Zarader

Matrix, machine philosophique

Paris: Ellipses, 2003

ISBN 2-7298-1841-3

$191 \mathrm{pp}$.

Matrix, machine philosophique (Matrix, philosophy machine) is the latest in a series of books devoted to teasing out the use of philosophy in, or the philosophical usefulness of, the immensely popular and influential 'Matrix' series. However, the book went to press before the release of The Matrix Revolutions, and thus does not represent the last word, if such were possible, on the deployment of philosophical topoi in the series. What it does do is try to think the manifest engagement of the first two films with various philosophemes as something other than either New Age syncretism or simply befuddled, pseudo-philosophical nonsense. Instead the authors look to the films as a sort of philosophical machine, equipped with a theoretical arsenal which, understood globally, is incoherent, but which is meant to empower the viewer to explore her own philosophical interests both in the specific act of interpretation and in a more general comportment of philosophical inquisitiveness facilitated by the unusually popular film.

The book consists of 12 articles, plus a long introduction and a useful glossary of terms and topoi, and the philosophers involved in the project are, with one exception, former students of the Ecole Normale Superieure in Paris -- the school that helped train, among others, Jean-Paul Sartre, Louis Althusser, and Michel Foucault. I assume that these young philosophers were all Normaliens together and studied under Alain Badiou, who is included in the bunch as sort of token master, but whose article is perhaps the least interesting in the collection (at any rate, the least interested in the films). The thinking of these philosophers obviously reflects their particular intellectual formation, and the collection has a more uniform and constant tone than, say, that edited by William Irwin under the title The Matrix and Philosophy. [1] This is not necessarily deleterious to the overall project, and makes the book more readable as a unified whole.

To my mind, one of the most interesting pieces in the Irwin book is the one that was actually co-written with a film scholar. Deborah Knight and George McKnight (Associate Professor of Film Studies at Carleton University, Ottawa), in 'Real Genre and Virtual Philosophy', draw attention to the philosophical suggestiveness already inherent in the various genres that are mixed together in The Matrix. 'Most of what counts as 'philosophical' is in fact already part of the film's genre inheritance' [2] from, for example, the Western (questions of choice and community), the Science Fiction film (Big Questions, theories of knowledge, metaphysics), the kung-fu action film (personal development, psychology, ethics), and so forth. The argument is that we should not expect that these philosophical topoi, borrowed as they are from the various genres structuring the film, are developed in philosophically interesting ways, but rather at best in generically interesting ways. Thus the film 'can only hope to use philosophical themes to trigger audience interest, but [was] never intended to provide a forum for the solution of philosophical problems ... The Matrix is unquestionably an example of real genre, but only an instance of virtual philosophy'. [3] I think this is a very important point to keep in mind. What conclusion one draws from the thesis, however, depends on how one treats genre. Is the film thus most interesting in its self-conscious positioning within genre history as well as informative in the ways that genres usually are (as relatively static systems for confirming and reproducing certain ideologies, or, if you will, as helpful tools for structuring popular understanding of self and society, love and camaraderie, and so forth); or on the contrary, is the film thus revealed as nothing more than stunning technical innovation and philosophical-religious suggestiveness in the service of a story as old as the hills (the standard group dynamic complete with wise figure, neophyte, love interest and traitor, the easily recognizable Good and Evil camps, the triumph of the hero in the end, the simplistic affirmation of community after the realization of an all too facile political struggle, etc.), not in the least philosophically, sociologically, or aesthetically interesting as narrative and quite the opposite of the 'revolutionary' one often hears ascribed to its visual technique? This, at any rate, would be one question within film 
studies.

Matrix, machine philosophique has different concerns, and never betrays the slightest sense of properly film historical or theoretical questions. Its concerns are philosophical. So, the caveat about film now stated, what are these concerns? Elie During, in the Introduction, announces the following guiding presupposition:

'The Matrix is neither a philosophical film nor filmed philosophy, indeed not even a film for philosophers ... [It] is a theoretical film, or more exactly a machine of theoretical effects, susceptible of interesting philosophers but not in the sense that one usually thinks ... [It] suggests theoretical trails by virtue of its own narrative or fictional constraints. One can exploit them and draw out philosophical effects, but only on the condition of understanding the priority of the function and operations of the total 'machine' of the film rather than its explicit or implicit philosophical content, in any case sufficiently disparate to evoke the suspicion of inconsistency. For The Matrix is not a patchwork, it is a machine' (7-8).

In its most basic sense, this means that at face value the film's philosophical content is shallow, inconsistent, incoherent, or what have you -- 'Introducing Plato in a futurist kung-fu film is an amusing idea, but once you add Schopenhauer, Descartes, Buddha, Jesus, the Gnostics, and theoreticians of artificial intelligence, the atmosphere quickly becomes stifling' (5). Therefore, if the film is to be seriously studied, its interest must lie elsewhere. Should the film be seriously studied? Two things are certain: first, that the film was extremely successful, but in a somewhat unusual way -- both a blockbuster and a cult classic, The Matrix is a generation-defining film like Star Wars, and one that has elicited youthful speculation (judging from chat rooms and web sites) of a much more proto-philosophical nature than the adventures of Luke Skywalker ever did. Second, and equally undeniable, is that the film is very useful for teaching philosophy. Of course we don't assign The Matrix instead of the Republic or the Meditations, but the film is a very useful touchstone to get students excited about Plato or Descartes, particularly helpful if you teach philosophy (and film) to non-philosophy (or film) majors as I do. Essentially, given the enthusiasm of a young generation of filmgoers (and potential philosophy readers) for The Matrix, we are obliged to take it seriously. As Zizek often says in his fluent Lacanese, 'Only the non-duped go astray'. The contributing philosophers to Matrix, machine philosophique accept the task, whatever the errant consequences.

David Rabouin, in an article entitled 'The Way of the Warrior', begins the discussion unexpectedly by questioning what The Matrix really is, as a film. Why did millions of people pay to see it? His answer is simply that it is because it is a cool king-fu movie. He seeks to show how this is not some annoying fact extrinsic to the theoretical or philosophical concerns of the film, nor the banal, generic truth of the film whose philosophical trappings are merely draped over the body of a straight-forward action flick. Instead, he suggests that the kung-fu elements and the philosophical speculation are inherently interrelated and intertwined. The kung-fu sequences are not just dubious aestheticizations of violence, nor the Hollywood flavor of the month, nor opportunities for MTV-style slow-mo fashion ads (all three reasonably valid suspicions), but are essential to the film as they chart a corporeal education, an awakening or enlightenment in fight in a unusual kind of materialization of the soul that escapes a mind-body dualism and draws its strength from various strands of Eastern philosophy. Neo's development into the One is as much a matter of martial arts training -- spiritually that is, above and beyond technique which after all was simply downloaded -- as of the Platonic education that leads out of the Cave of semblance. Rabouin reviews writings from ancient and contemporary traditions in martial arts about, for example, motion and stasis, corporeal spirit, and the voiding of the intellect in order to free the body from fear, constraint, and so forth. He then extends this sort of inquiry (in a second text, 'The Tao of the Matrix') with reference to Taoist and Buddhist philosophy. The problem, of course, is that although there is something of a parallel established between the world of illusion (the Cave) and the Buddhist concept of samsara, the path to nirvana does not lead here to a complete renunciation of the idea of self or to some enabling spiritual exhaustion (see the book's appendix entry on 'Exhaustion') -- despite the example of the 'Spoon boy' among the potentials at the Oracle's slum flat -- but actually to the affirmation of a Christ-like self, renounced, if at all, through sacrifice, which is something quite different from the goal of a Bodhisattva. In other words The Matrix is not a Taoist or Buddhist film any more than a 'philosophical' one of any particular stripe. Still, the article is quite suggestive in its illustration of clear links to various Eastern philosophical traditions.

The martial arts emphasis of The Matrix is perhaps the most striking thing about the film. The memorable mise-en-scene is essentially tied to this aspect rather than, say, the sci-fi elements of the overall conception. For the brilliant sci-fi scenario of The Matrix simply represents life in 1999 in a modern city (reminiscent of Sydney), and as we know, the real is a 'desert'. So the style derives, in costumes and sets, from the leather, latex, and sunglasses cool of our heroes in a Matrix-world of contemporary chrome, marble, and leather (contrasting, of course, with the slums and back alleys which were necessary for humans to accept the Matrix program -- which according to Agent Smith did not work when the simulated life was devoid of pain, sorrow, and suffering). This is productively complemented by the cinematography: the well-known martial-arts alternation of pace (slow-motion sequences contrasting with rapid montage editing and manipulative sound editing) and distance (establishing full shots and extreme long shots alternating with synechdochal close-ups and extreme close-ups) to produce the jarring thrill and exhilaration of the fights. This is innovatively extended by the famous 'bullet time' sequences designed by John Gaeta, which are really just a brilliant intensification of the slow-motion action sequences common in films coming out of Tokyo and Hong Kong (at least since early Kurosawa and commonplace by the late 60s and early 70s), but with the added benefit of disorienting us in a way that seems appropriate to the mind-experiment idea of the Matrix. Thus the martial arts aspects of the film are not only absolutely crucial to its visual style, they are also related to some of its major theoretical emphases.

The Matrix is a Bildungsfilm, whether in terms of a martial arts apprenticeship to some 'black-belt' mastery or Buddhist self-negation, or a Platonic escape from murky semblance to the bright light of formal truth and beauty. So an important question is: Where does this lead Neo (or us) in the end? This opens on to two of the major questions philosophers have discussed with respect to The Matrix. First, what is the relationship of the film to Plato's allegory of the cave?; [4] and second, what is wrong with living in the Matrix? At least half of the articles in Matrix, machine philosophique are devoted to these questions. In 'The Matrix or the Cave?' Thomas Benatouil explores the obvious but not always clear relation of the film to its famous philosophical source. The initial analogy is obvious: Neo is caught in a world of illusion that he (and everyone else) understands to be real and true. [5] However, Neo already has an (unexplained) sense of uncertainty about his world -- the 'splinter in the mind' -- and is thus primed for his interpellation by Morpheus and his gang. [6] Thus a 
master who has escaped from the cave intervenes -- the obvious analogy in Plato is of course Socrates himself. [7] Neo chooses the red pill and embarks on his journey of discovery -- because ultimately, to know the Matrix, you have to step out of it yourself. [8] So far so good, but here is where the stories diverge, according to Benatouil. Rather than 'Forms' and so forth, Neo finds a post-apocalyptic 'desert' of the real -- a world in almost every respect much less appealing than the Matrix, but (we are given to understand) a world nonetheless of freedom and truth. Neo must then acquire a superior mastery of his virtual body in order to liberate his spirit. Benatouil argues that while for Socrates,

'the importance was to work on one's soul rather than on one's body in searching to define moral virtue [and] for Plato this was only realized through the knowledge of intelligible realities accessible only if the soul turns away from sensible objects, for Neo ... it is not a question of discovering new objects with unheard of properties, but embracing illusion itself with a mastered, lucid gaze' (37).

Ultimately the project isn't a Platonic one concerned with the education of rulers (or even a personal, philosophical education to escape the traps of the world of illusion), but one concerned with liberation through and within the Matrix itself. This is marked by the acquisition of a certain distance with respect to one's own virtual actions within the Matrix (already present in the abilities of Morpheus and Trinity, but epitomized in the final battle in the first film between Neo and Smith). Thus Neo's knowledge leads to perfection within the Matrix, to vision of the digital structure itself. This conclusion (to the first film) clearly has very little to do with Plato.

It is here that Benatouil takes recourse to the thought of a philosopher present throughout Matrix, machine philosophique but entirely absent from Irwin's collection (a sign of the different intellectual institutional formations): Benedict de Spinoza. In some ways, this is the most interesting philosophical development in the book vis-a-vis Irwin's or the essays collected in the Philosophy section of the film's website. [9] Benatouil reviews several aspects of Spinoza's complicated and vast system, especially his theory of knowledge according to which three types are distinguished: first, opinion or imagination; second, reason; and finally, 'intuition' which 'proceeds from an adequate idea of the absolute essence of certain attributes of God to the adequate knowledge of the essence of things': [10]

'Spinoza explains at the end of the Ethics that the capacities for action of a body increase with the development by the spirit of this third type of knowledge and that it gives man the highest possible satisfaction. The spirit in particular thus understands how its own existence and that of the body depend on and flow from God, that is, Nature' (40). [11]

This knowledge leads to an 'intellectual love of God'. [12] Taken out of context -- necessarily given the complexity of the proper context -- this reference to Spinoza does put an interesting spin on the 'education' of Neo to a mastery of the Matrix. Benatouil concludes with a suggestive comment:

'We must then ask whether, in becoming the One, Neo isn't necessarily driven to love the Matrix, to participate with joy in its intimate and necessary rationality. Such is one of the possible interpretations of the pleasure that Neo takes in exercising his powers in the Matrix and of the final promise he makes of showing men 'a world without rules and controls, without borders or boundaries'. Could this world really be the post-apocalyptic cesspool of the Nebuchadnezzar and Zion, the promised but arid land of the real? Or is it perhaps the Matrix itself, offered as a new world to the powers of a humanity which has acceded to the truth of the Matrix, that is, mastery of the virtualities immanent to its plastic structure, rather than to a ghostly reality 'outside of the cave', (41-42).

Now, it should be pointed out that 'intuition', this third type of understanding in Spinoza, is the way we come to terms with our complete lack of free will, for this love and understanding is of the whole system of Nature in God: 'In the mind there is no absolute or free will; but the mind is determined to wish this or that by a cause, which has also been determined by another cause, and this last by another cause, and so on to infinity'. [12] As is clear in the first film (and irritatingly insistent in the second and third), Neo -- and the trilogy in general -- is obsessed with the idea of choice versus determinism, individual agency versus mystical destiny: free individual choice within the Matrix as absolute determinism sub specie aeternitatis, that is, from the standpoint of the Architect or even the Merovingian (perhaps an earlier Neo who has also come to understand Necessity, but in a cynical rather than beatific way); and free individual choice as destiny from the standpoint of faith in a prophecy -- the Oracle, Morpheus. By the end of The Matrix Reloaded, and Neo's confrontation with the Architect, our increasing sense of his liberty of choice has become undermined by the idea that his messianic rebellion is, as it were, scripted by the program in the first place -- as a sort of systemic cleansing mechanism that compensates for the unavoidable rejection of the Matrix by one percent of the human subjects. Therefore what we can conclude, knowing the messianic selfsacrifice at the end of The Matrix Revolutions, is still debatable. Benatouil, focusing mainly on the first film, opts for a more Spinozan understanding, a particularly ingenious one in the philosophical history of the topic.

This, then, leads us to the second major philosophical issue of the film: essentially the moral and political repercussions of the skeptical conceit. To my mind, this question is best treated by Hubert and Stephen Dreyfus in 'Existential Phenomenology and the Brave New World of The Matrix'. [14] What is wrong with living in the Matrix? There is certainly a tone of victimization and consequent political self-righteousness to Morpheus's discussions of the Matrix and the real world. From the Cartesian hypothesis of the Evil Deceiver (meant to test the ontological foundations of his philosophical system [15]) to contemporary philosophical scenarios of brains in vats (Hilary Putnam's for example -- used to illustrate a critique of 'mystical' notions of reference [16]), the skeptical hypothesis is a very familiar modern topos. How can we know we are not in such a situation? And -- what occupies us more here -- why is it so bad if we are? The Dreyfus' explore the details of the scenario, accepting the brain in vat situation and teasing out its consequence: 'It's a mistake to think that each of us is experiencing a set of neural firings in a brain in a cranial vat. True, each of us has a brain in his or her skull and the brain provides the causal basis of our experience, but we aren't our brain' . [17] What is the nature of the 'us' involved in the scenario? The Dreyfus' continue: 'It is important to bear in mind that a body in a vat doesn't have a human personality apart from the active, vulnerable, feeling person in the Matrix of whom it is the causal basis ... [Moreover], to be the causal basis of a person is not to be a person'. This is to say that the idea that the body or brain in the vat is somehow the real person who is being manipulated or enslaved and that the virtual person in the Matrix is somehow only virtual does not make any sense. The human beings in the vats are being used for energy to sustain the world of the machines, but, 'having your causal basis used for some extraneous purpose is not per se enslaving. That is, although the Matricians' causal basis is being used to generate electricity, the Matricians themselves are not being used'. So what is wrong about the situation? Here the Dreyfus' present a Heideggerian intervention, claiming that the problem isn't 
epistemological (that all our knowledge is false because it relates to a world of illusion and not to reality), nor metaphysical (that because of epistemological limitations in our experience and understanding of the world, we cannot possibly have a systematic understanding of the world, we are entirely deluded about its origins and limits, and we have no basis for speculating about its meaning, etc.), nor even political (that we are oppressed subjects unable to realize our own political choices and enjoy fundamental rights, and so forth): 'The problem is what Heidegger would call ontological. It has to do with the Matricians' freedom to choose all right, but not with a limitation on choice in the current world, but a limitation on their freedom to disclose new worlds -- to transform their understanding of being'

Benatouil extends this discussion in his second piece, 'Are We in the Matrix?' arguing that the fact that the Matrix is literally a world of illusion in no way makes it unviable for living:

'The simulation is first of all much less deceptive than most skeptical hypotheses: the principal elements of the Matrix, material reality, the Earth, our bodies, the details of human faces, communication with others, civilization at the end of the twentieth century, exist or have existed outside of the Matrix and are not therefore pure fictions [therefore not purely false] . . In reality, what is objectionable about being inside of the Matrix is not its simulated dimension but the fact that it is controlled by machines which, after a war with humans, hold them captive in the Matrix ... [And] it is not the world or ourselves that the Matrix travesties to us or confiscates from us, but our own collective history, however terrible it might be' $(115,116$, and 118).

Whether one agrees with Benatouil or the Dreyfus', the argument has thus shifted from an epistemological level proper to the skeptical philosopheme, to an ontologico-political level: what makes humans human is their relationship to their collective history and future, that is, the ability to interpret past human events and change the human world. This is obviously an inflection that opens more fruitfully on to other concerns of the film, especially those relating to and structured by the messianic-revolutionary myth. Neo can seek to liberate humans only with the insight that they are denied knowledge of their past and their ability to transform their futures within the Matrix (and not necessarily outside in the grim 'real' world, an ambiguity that The Matrix Revolutions does well to sustain at its conclusion).

This is a very interesting way of reading the hypothesis because it puts the ethical-political (-ontological) onus of the film not necessarily on liberation from the world of simulation and virtuality, but simply on a political project of changing that (virtual) world. This harmonizes with a strong sense, in this viewer at any rate, that the sequences of the trilogy within the Matrix are far more interesting than the dull, cliched visions of political resistance. Not in that they are cooler and sexier -- which is quite obvious -- but in how they open on to much more challenging and speculative philosophical questions. I remember reading a review by Stuart Klawans in The Nation [18] which sketched the opposite reading, trying to recuperate something of this political emphasis in the midst of a squarely Hollywoodian, stylized entertainment film that really does often look like little more than an ad for itself (as Adorno would say [19]), but the more I think about 'the philosophy of the Matrix', the more this seems misleading. What is the nature of political struggle in Zion? First of all, there is the outright, uncomplicated, evil oppression of the remaining humans by the machines. In the resistance, we have two camps: the rigid, rationalist military camp exemplified by Commander Lock, and the mystical, prophetic group under Morpheus. We also have the traitors: first Cypher, then Bane. We have the stereotypical team (as Badiou points out in his article 'Dialectics of the Fable'), and a vague political structure with a (presumably representative) council of very serious and pompous individuals, as much reminiscent of some feudal Jedi league as of a coalition government representing various confederated constituencies. Now, Zion is remarkable for its diversity -- we seem to be in a time beyond insidious perceived racial distinctions -- but, to quote Cynthia Freeland, what we are really dealing with is the same old shit.

Freeland, in 'Penetrating Keanu: New Holes, but the Same Old Shit', [20] explores several aspects of the politics of the image and selfglorification in The Matrix. She is particularly interested in the predictably limited role of Trinity in the film, and contrasts the depressingly standard sexism of the film to the more intriguing gender dynamic in Cronenberg's eXistenZ. I agree wholeheartedly with this criticism, and will only add that the narrative structure itself could hardly be more numbingly hackneyed -- thoroughly 'predigested and already integrated'. [21] The sexual politics of the film in no way escape this unchallenging ideological structure, and it should be pointed out that despite the almost parodically sexy skin-tight outfits, cool shades, and slow-mo corporeality of the film, it is in every sense as chaste, prudish, and wholesome as Star Wars was so many years ago. It seems you can make great advances in technique and philosophical speculation, but only if you construct your film on the most customary and cliched ideological and formal foundations.

Further, the choice of the thumping Rave, after Morpheus's portentous contribution to the post-apocalyptic pep rally, seems infelicitous in its trivialization of the idea of political community. It is a shame that the quasi-Spinozan sophistication in the conception of free will and philosophical development emphasized in Matrix, machine philosophique was not paralleled by a Spinozan nuance in the imagination of some really new political configuration, as in his novel, 'non-mystified' materialist conception of democracy and collective freedom. [22] In any case, politics gets lost to the generic siege sequence which seems to take up at least half of The Matrix Revolutions, and ultimately the community is only justified and saved by messianic sacrifice.

Alain Badiou's contribution to the collection ends with the pregnant comment:

'It is the principle of the art of the cinema to show that it is only cinema, that its images only bear witness to the real insofar as they are manifestly images. It is not in turning away from appearance or in praising the virtual that you have a chance of attaining Ideas. It is in thinking appearance as appearance, and therefore as that which from being comes to appear, gives itself to thought as deception of vision' (129).

This works well as a summary of the Spinozist-Buddhist-Taoist interpretation of The Matrix developed in Matrix, machine philosophique. This reading applies most to the first film, and it is perhaps circumspect to limit one's study of the philosophy of the Matrix trilogy as much as possible to that episode. The other articles in the collection explore other philosophical aspects of the first two films: simulation, mechanization, myth, theology, and artificial intelligence. The idea is that you cannot limit the film to any one of these particular interests, nor to some vague, syncretic integration of all of them. Rather, the film leads us into different, incommensurable, and sometimes incomprehensible theories and philosophemes, opening on to and empowering the viewer's choice of interpretation and speculation. I think it is clear from the amount of work published so far by a number of respectable philosophers that in this capacity as 
well the film has been very successful. Matrix, machine philosophique is a useful contribution from the French in this on-going discussion.

Notes

1. William Irwin, ed., The Matrix and Philosophy (Chicago: Open Court, 2002).

2. Deborah Knight and George McKnight, 'Real Genre and Virtual Philosophy', in Irwin, ed., The Matrix and Philosophy, p. 190.

3. Ibid., pp. 200-201.

4. See book VII (sections 514a - 521b) of Plato's Republic, trans. G. M. A. Grube (Indianapolis: Hackett, 1992).

5. See book VII, section 515c of the Republic.

6. Something like Platonic recollection, admittedly absent from the Cave analogy, but present elsewhere in the dialogues, and developed in a way more appropriate to this context in Plotinus and the Neo-Platonic tradition -- e.g. book IV, section iii of Plotinus, The Enneads, trans. Stephen Mackenna (New York: Penguin, 1991), pp. 25ff.

7. See book VII, section 517a or the Republic.

8. See book VII, section $515 \mathrm{~d}$ or the Republic.

9. See $<$ http://www.whatisthematrix.com>.

10. Benedict de Spinoza, 'Ethics', in On the Improvement of the Understanding, Ethics, and Correspondence, trans. R. H. M. Elwes (New York: Dover, 1955), Part II, Prop. XL, Note 2, p. 113.

11. See Ibid., Prop. V, p. 30.

12. Ibid., Prop V, pp. 33 ff. This point is also explored by Patrice Maniglier in his contribution, 'The Power of Love'.

13. Ibid., Prop. II, p. 48.

14. Available online at file://localhost/<http/::www.whatisthematrix.com $>$.

15. See Rene Descartes, 'Meditations', in A Discourse on Method, Meditations, and Principles, trans. John Veitch (London: Everyman, 2003).

16. See Hilary Putnam, 'Brains in a Vat', in Reason, Truth, and History (Cambridge: Cambridge University Press, 1981).

17. Dreyfus and Dreyfus, 'Existential Phenomenology and the Brave New World of The Matrix', <http://www.whatisthematrix.com>, no page numbers.

18. Stuart Klawans, 'Medium Cool', The Nation, July 9, 2003.

19. See Theodor W. Adorno, 'Transparencies on Film', in The Culture Industry, ed. J. M. Bernstein (London: Routledge, 1991).

20. Cynthia Freeland, 'Penetrating Keanu: New Holes, but the Same Old Shit', in Irwin, ed., The Matrix and Philosophy.

21. Adorno, 'Transparencies on Film', p. 182.

22. See Antonio Negri, The Savage Anomaly, trans. Michael Hardt (Minneapolis: University of Minnesota Press, 1991).

Duncan Chesney, 'Spinoza and the Politics of The Matrix: On Matrix, machine philosophique', Film-Philosophy, vol. 8 no. 25, August $2004<$ http://www.film-philosophy.com/vol8-2004/n25chesney>.

Back to Top

- About this Journal

- Editors and Editorial Board

- Conferences

- $\underline{\text { Indexing }}$

\section{About this Journal}

\section{Fully Open Access}

Film-Philosophy is an open access peer-reviewed academic journal dedicated to the engagement between film studies and philosophy. The journal is interested in the ways in which films develop and contribute to philosophical discussion. We particularly welcome articles that set up an active engagement between film studies and philosophy, thereby sustaining a thoughtful re-evaluation of key aspects of each discipline. 
There has been an increasing interest in film-philosophy as a discipline within Film Studies since the 1990s and Film-Philosophy itself has played an important role in this development. We provide an important avenue for publication in the field of film and philosophy.

\section{Editors and Editorial Board}

\section{Editor-in-Chief}

Dr David Sorfa, University of Edinburgh

\section{Editorial Board}

Dr Lucy Bolton, Queen Mary, University of London - Social Media Manager Dr William Brown, University of Roehampton, London - Book Reviews Editor Professor Catherine Constable, University of Warwick

Dr Matthew Holtmeier, Ithaca College, USA

Dr Tarja Laine, University of Amsterdam

Professor David Martin-Jones, University of Glasgow

Dr Matilda Mroz, University of Sussex

Professor John Mullarkey, Kingston University, London

Dr Richard Rushton, University of Lancaster - Conference Manager

Dr Robert Sinnerbrink, Macquarie University, Australia

Dr Ben Tyrer, University of Exeter

Dr Catherine Wheatley, King's College London

\section{Advisory Board}

Jon Baldwin, London Metropolitan University

Professor Sarah Cooper, King's College London

Dr Andrew Klevan, University of Oxford

Dr Douglas Morrey, University of Warwick

Professor Benjamin Noys, University of Chichester

Dr Richard Stamp, Bath Spa University

Professor Damian Sutton, Coventry University

\section{Conferences}

The Film-Philosophy Conference is an annual academic conference associated with the Film-Philosophy Journal. The conference has been running since 2008 and takes place at a different university every year. For more information please visit http://www.filmphilosophy.com/conference.

\section{Indexing}

Film-Philosophy is abstracted and indexed in the following:

- Annual Bibliography of English Language and Literature (ABELL)

- British Library Zetoc

- BrowZine

- CNKI (China National Knowledge Infrastructure)

- cnpLINKer

- Directory of Open Access Journals (DOAJ)

- EBSCO A-to-Z

- EBSCO Discovery Service

- European Reference Index for the Humanities (ERIH PLUS)

- FIAF International Index to Film Periodicals

- J-Gate

- JournalTOCs

- Meta Indexing

- MLA (Modern Language Association) International Bibliography

- Philosopher's Index

- PhilPapers

- ReadCube Discover

- Summon

- TDNet

- Web of Science/Emerging Sources Citation Index

- WorldCat Discovery 
$\underline{\text { About this Journal Editorial Board Submit an Article }}$

Subscribe / Renew

Table of Contents Alerts

$\underline{\text { Submit an Article }|\underline{\text { Librarian Free Trial }}| \text { Mailing List }}$

\section{Journal News}

News

Advertise Your Film Studies Course With EUP

\section{Journal Subjects}

- Archaeology

- Architecture

- Botany

- Film, Media \& Cultural Studies

- History

- Islamic Studies

- Language \& Linguistics

- Law

- Literary Studies

- Philosophy

- Politics

- Religious Studies

- Science \& Social Science

- Scottish Studies

- $\underline{\text { All }}$

\section{Librarian Services}

- Registration

- Activation

- Usage Statistics

- Journal Ordering and Pricing

- $\underline{\text { Renewals }}$

\section{General Resources}

- Search Journals

- Journal Ordering and Pricing

- Catalogues

- Author Services

- Permissions

- Browse for Books

- Contact Information

- Website Feedback

- Access Token Activation

- Mailing List

Copyright $(C 2019$. Edinburgh University Press.

News Blog@EdinburghUP Facebook

Loading [Contrib]/a11y/accessibility-menu.js $\mid$ Contact Us 